\title{
First Observations on Zooplankton and Optical Properties in a Glacial North Patagonian Lake (Tagua Tagua Lake, $41^{\circ} \mathrm{S}$ Chile)
}

\author{
Patricio De los Ríos-Escalante ${ }^{1,2 *}$, Patricio Acevedo ${ }^{3,4}$ \\ ${ }^{1}$ Universidad Católica de Temuco, Facultad de Recursos Naturales, Escuela de Ciencias Ambientales, \\ Laboratorio de Ecología Aplicada y Biodiversidad, \\ Casilla 15-D, Temuco, Chile \\ ${ }^{2}$ Núcleo de Estudios Ambientales, UC Temuco \\ ${ }^{3}$ Universidad de La Frontera, Departamento de Ciencias Físicas, \\ Casilla 54-D, Temuco, Chile \\ ${ }^{4}$ Center for Optics and Photonics, Universidad de Concepción, \\ Casilla 4012, Concepción, Chile
}

Received: 27 July 2015

Accepted: 9 September 2015

\begin{abstract}
The Patagonian lakes are of glacial origin and some of these are associated with glaciers that generate specific optical properties such as water colorations due to glacier sediments. These lakes also are oligotrophic with a low crustacean zooplankton species number. The aim of the present study was to analyze potential associations between optical properties and zooplankton communities in Tagua Tagua Lake $\left(41^{\circ} \mathrm{S}\right)$. The results revealed inverse associations in reflectance of bands 3 and 7 of LANDSAT TM+ with Daphnia ambigua, Mesocyclops araucanus, and nauplius, and direct Neobosmina chilensis and Cyclopoids copepodites, whereas it was inverse relations between bands 5 and 2 with $B$. gracilipes and calanoid copepodites that make this zooplankton assemblage similar to Nord Patagonian oligomesotrophic lakes. These results would agree with few reports for other similar Patagonian lakes of glacial origin reported for Argentinean and Chilean Patagonia. Nevertheless, it is necessary for more studies to find potential associations between limnological characters and optical properties.
\end{abstract}

Keywords: glacier, optical properties, reflectance, zooplankton

\section{Introduction}

The Patagonian lakes located in southern Argentina and Chile (38-51 $\left.{ }^{\circ} \mathrm{S}\right)$ are of glacial origin [1-3], and some of these lakes have associated ice fields in their surrounding

*e-mail: prios@uct.cl basins that generate specific characteristics in landscapes such as that observed in Grey Lake in Torres del Paine National Park [4], or water colorations specific for each lake, for example the greenish bays in General Carrera or Todos los Santos lakes [1,5]. Also, the Patagonian lakes are characterized by their marked oligotrophy [1] generated in consequence of the low crustacean zooplankton species 


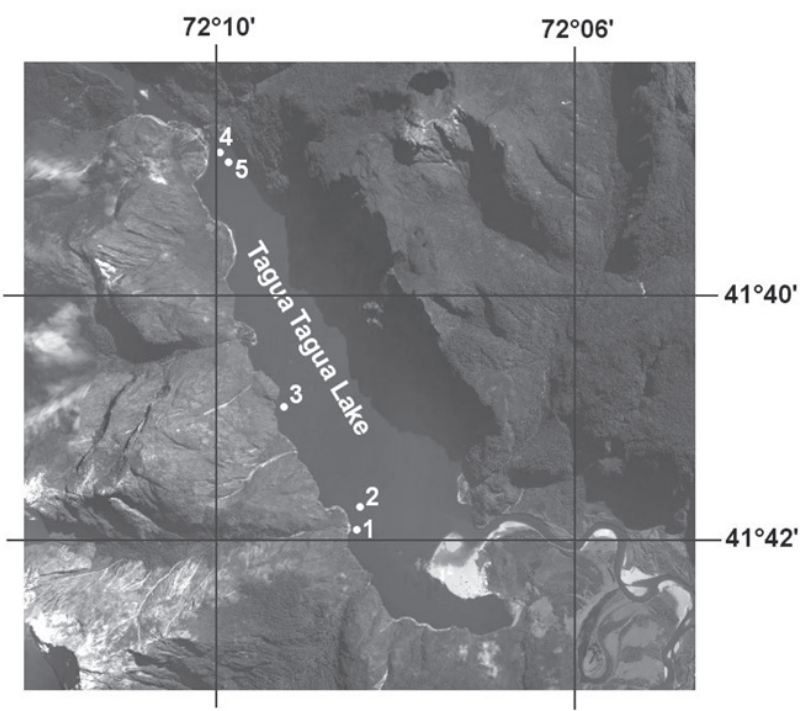

Fig. 1. Satellite image of Tagua Tagua Lake with sampled sites.

richness and marked predominance of calanoids copepods of genus Boeckella and Tumeodiaptomus [1].

In this scenario, the oligotrophy that can be enhanced by the presence of glacial salts would generate an additional light limitation due to the low penetration of photosintetically active light [1], and this scenario would affect the zooplankton communities such as those observed in preliminary observations of General Carrera Lake in Chile using remote sensing techniques [5]. The aim of the present study is to study the zooplankton assemblage in Tagua Tagua Lake and its potential association with optical properties using remote sensing techniques.

\section{Materials and Methods}

Study site: Tagua Tagua Lake belongs to the Puelo Lake system and river basin that involves Argentina and Chile and has numerous lakes and rivers in a mountain zone with difficult access due the mountains and strong winds that complicate sampling work (Fig 1).

Sampling procedures: five sampled sites were georeferenced using a Garmin GPS unit, and zooplankton samples were taken using vertical hauls of $15 \mathrm{~m}$ with plankton net of $20 \mathrm{~cm}$ diameter and $100 \mu \mathrm{m}$ mesh size. Zooplankton specimens were fixed in absolute ethanol identified with specialized literature $[6,7]$ and quantified in laboratory. The site was visited on 10 April 2013. Sechi disk for all sampled sites was $3 \mathrm{~m}$.

Remote sensing procedures: in this step we used a LANDSAT/ETM+ image obtained on April 2013 (Fig. 1) provided by the Land Processess Distributed Active Archive Center (LP DAAC) of the U.S. Geological Survey (http://LPDAAC.usgs.gov). The bands of visible, near, and mid-infrared were calibrated radiometrically to spectral irradiance and then to reflectance with atmospheric correction being applied (Table 1).

Data analysis: reflectance and zooplankton abundances were applied in a principal correspondence analysis to obtain the grouping for sampled sites, and in this analysis a Pearson correlation analysis was considered. This statistical analysis was applied using Xlstat 11.0 software.

\section{Results}

The results revealed low species number that varied between two species in sites 2 and 3 , three species for sites

Table 1. Geographical location, reflectance, and zooplankton composition for studied sites.

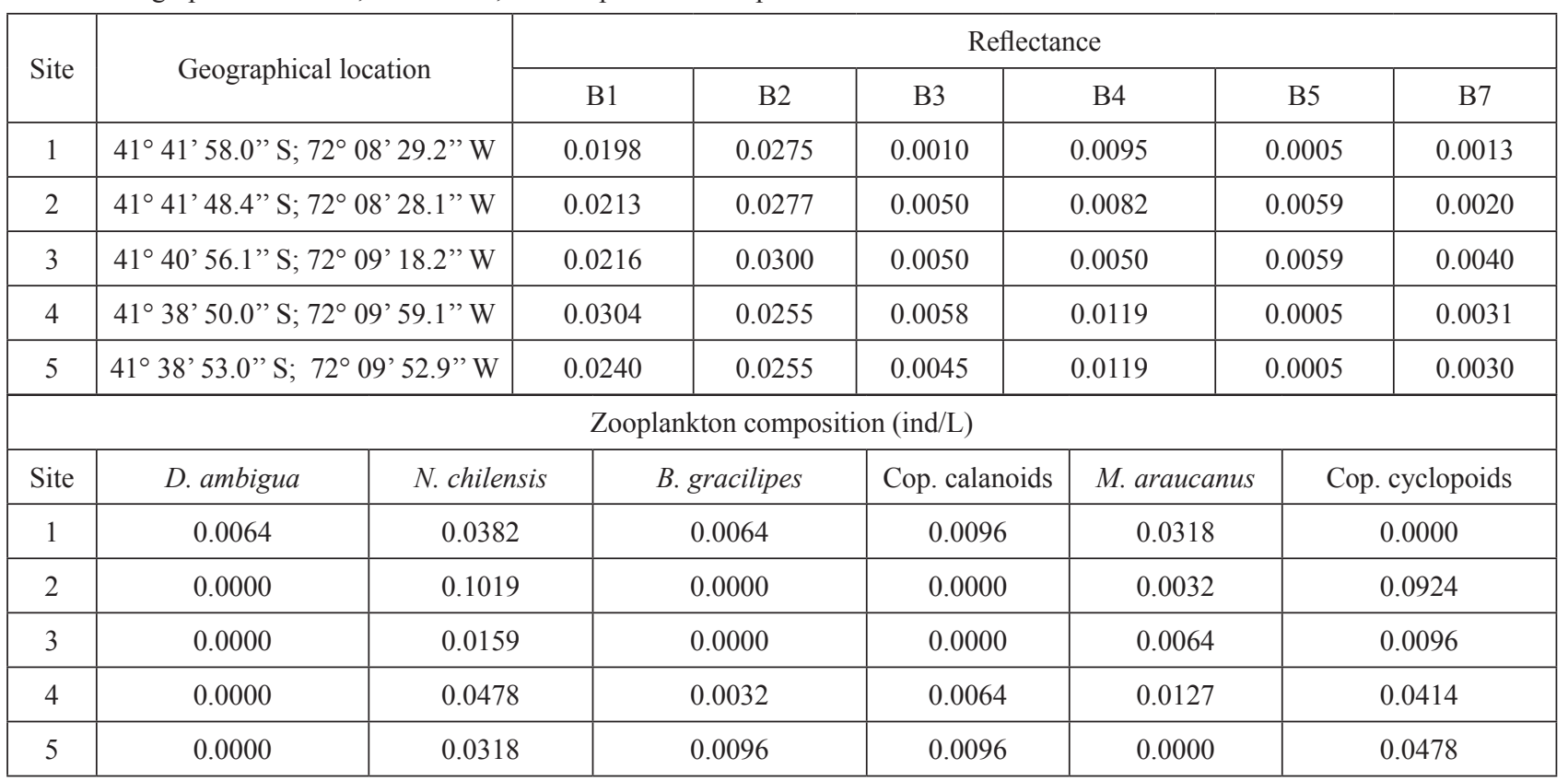




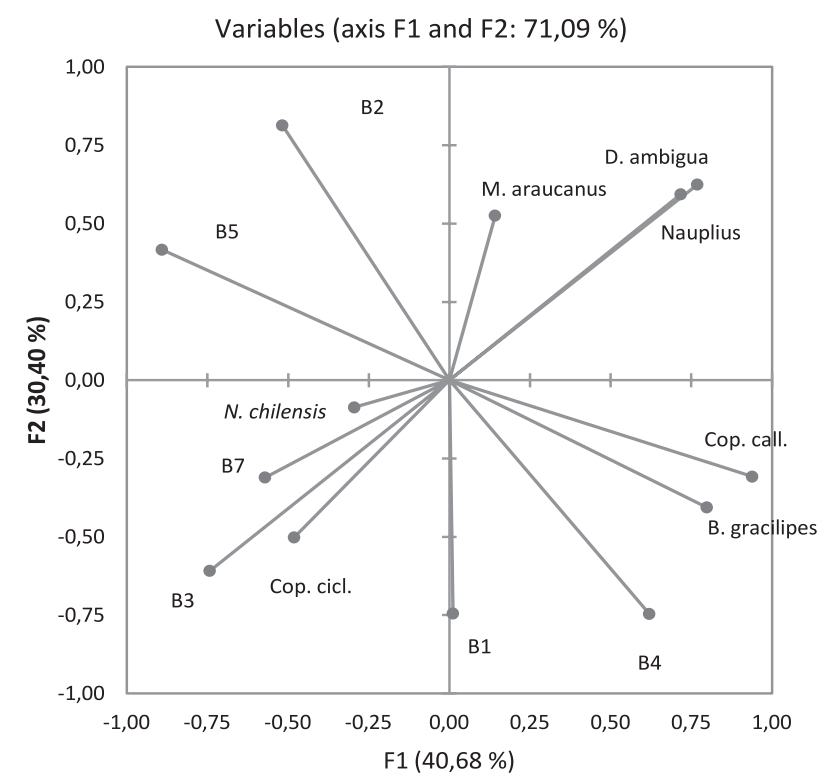

Fig. 2. PCA analysis for variables considered in the present study.

4 and 5, and four species for site 1 . The species reported were Daphnia ambigua, Neobosmina chilensis, Boeckella gracilipes, and Mesocyclops araucanus (Table 1). Sites 1, 2 , and 3 have high values for $\mathrm{B} 2$ and low values for B7, whereas site 4 has high value for B1 and low value for $\mathrm{B} 5$, and site 5 has high value for $\mathrm{B} 2$ and low value for $\mathrm{B} 5$ (Table 1).

The correlation analysis revealed direct significant correlations between B1 with B3 and B4, B2 with B5, $\mathrm{B} 3$ with $\mathrm{B} 7$, and $\mathrm{B} 4$ with $B$. gracilipes and calanoids copepodites, D. ambigua with calanoids copepodites and M. araucanus, B. gracilipes with calanoid copepodites, and $M$. araucanus with Nauplius. Also we found significant inverse relations between $\mathrm{B} 1$ with $\mathrm{B} 2$; B2

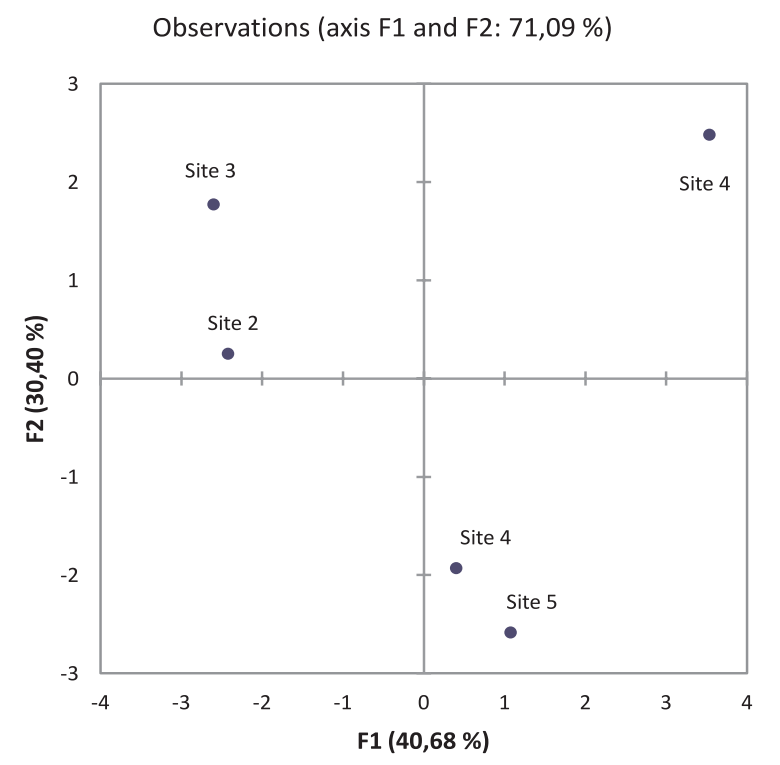

with B4, B. gracilipes, and Calanoids copepodites; B3 with $D$. ambigua and $M$. araucanus; B4 with B5; B5 with $B$. gracilipes with calanoid copepodites; B7 with $D$. ambigua, N. chilensis, and $M$. araucanus; D. ambigua with cyclopoids copepodites; and $M$. araucanus with Cyclopoids copepodites (Table 2).

The PCA revealed that the main contributor variables for axis 1 were B3, B5, calanoids copepodites, $B$. gracilipes, and $D$. ambigua, whereas for second axis the main variables where B1, B2, and B4 (Fig. 2, Table 3). Site 1 has low B5 and B7 reflectances and high D. ambigua, $M$. araucanus, and nauplius abundance, whereas sites 2 and 3 were high B2 and B5 reflectance and low zooplankton abundance, and finally sites 4 and 5 were high B1

Table 2. Correlation matrix for variables considered in the present study; values in bold denote significant correlation $(\mathrm{p}<0.05)$.

\begin{tabular}{|c|c|c|c|c|c|c|c|c|c|c|c|c|}
\hline Variables & B2 & B3 & B4 & B5 & B7 & $\begin{array}{c}\text { D. } \\
\text { ambigua }\end{array}$ & $\begin{array}{c}N . \\
\text { chilensis }\end{array}$ & $\begin{array}{c}B . \\
\text { gracilipes }\end{array}$ & $\begin{array}{l}\text { Cal. } \\
\text { Cop. }\end{array}$ & $\begin{array}{c}M . \\
\text { araucanus }\end{array}$ & $\begin{array}{l}\text { Cycl. } \\
\text { Cop. }\end{array}$ & Nauplius \\
\hline B1 & -0.643 & 0.628 & 0.603 & -0.430 & 0.408 & -0.484 & -0.057 & 0.068 & 0.191 & -0.212 & 0.169 & 0.107 \\
\hline B2 & & -0.111 & -0.992 & 0.787 & 0.215 & 0.078 & -0.155 & -0.661 & -0.699 & 0.056 & -0.317 & 0.219 \\
\hline B3 & & & -0.001 & 0.359 & 0.723 & -0.969 & 0.178 & -0.434 & -0.524 & -0.810 & 0.549 & -0.239 \\
\hline B4 & & & & -0.855 & -0.272 & 0.039 & 0.090 & 0.718 & 0.777 & 0.057 & 0.212 & -0.170 \\
\hline B5 & & & & & 0.279 & -0.408 & 0.328 & -0.840 & -0.963 & -0.435 & 0.319 & 0.000 \\
\hline B7 & & & & & & -0.737 & -0.516 & -0.253 & -0.368 & -0.610 & -0.114 & -0.312 \\
\hline D. ambigua & & & & & & & -0.152 & 0.343 & 0.516 & 0.928 & -0.586 & 0.456 \\
\hline N. chilensis & & & & & & & & -0.370 & -0.359 & -0.181 & 0.850 & 0.140 \\
\hline B. gracilipes & & & & & & & & & 0.936 & 0.173 & -0.235 & -0.470 \\
\hline Calanoids cop. & & & & & & & & & & 0.447 & -0.360 & -0.135 \\
\hline M. araucanus & & & & & & & & & & & -0.644 & 0.719 \\
\hline $\begin{array}{l}\text { Cyclopoids } \\
\text { cop. }\end{array}$ & & & & & & & & & & & & -0.303 \\
\hline
\end{tabular}


Table 3. PCA contribution percentage of variables for axis 1 and 2 .

\begin{tabular}{|c|c|c|}
\hline & F1 & F2 \\
\hline B1 & 0.003 & 14.049 \\
\hline B2 & 5.065 & 16.739 \\
\hline B3 & 10.427 & 9.380 \\
\hline B4 & 7.273 & 14.097 \\
\hline B5 & 15.005 & 4.386 \\
\hline B7 & 6.168 & 2.443 \\
\hline D. ambigua & 11.185 & 9.866 \\
\hline N. chilensis & 1.640 & 0.192 \\
\hline B. gracilipes & 12.061 & 4.177 \\
\hline Calanoids cop. & 16.683 & 2.402 \\
\hline M. araucanus & 9.739 & 8.906 \\
\hline Cyclopoids cop. & 4.373 & 6.380 \\
\hline Nauplius & 0.381 & 6.983 \\
\hline
\end{tabular}

reflectance and B. gracilipes and calanoids copepodites abundances (Fig 2).

\section{Discussion}

The results described above agree with results obtained for other lakes of glacial origin, for example lakes Sarmiento and Del Toro in the Torres del Paine National Park [8], and General Carrera Lake [6], where the markedly abundant calanoid species $B$. gracilipes Daday, 1901 and/or B. michaelseni are associated with low abundances of cyclopoid copepods and the cladoceran $N$. chilensis. Similar results were observed for other glacial oligotrophic lakes in Torres del Paine National Park, such as Nordsdenkjold and Grey, where the zooplankton communities consist of only two species (B. michaelseni and Tropocyclops prasinus [9]. This situation differs from that of another Patagonian lake with glacial influence, Todos los Santos Lake, which has four species [1].

Zooplankton communities can be affected by glacial influence. In marine environments zooplankton mortality, mainly associated with the chemical properties of the ice, has been found in areas close to ice fields $[10,11]$. For Patagonian lakes the glacial influence is water turbidity due to glacier sediments and dissolved organic matter, which prevent light penetration into the water column [12, 13], with the consequences in photosynthesis activity that involve a biogeochemical process of nutrient inputs from phytoplankton that are grazed by zooplankton, such as those observed in Argentinean Patagonian lakes [13]. This would make it similar to some lakes with glacial influence in Torres del Paine National Park, where only two species are found [1,9]. The results presented indicate that a potential correlation between zooplankton assemblages and optical properties might possibly be found; however, it would be necessary to carry out more intensive studies and obtain more data to be able to confirm or discount the possibility of finding potential correlations.

\section{Acknowledgements}

The present study was funded by project Nos. TIDES TRF13-03011 and MECESUP UCT 0804. We thank the staff of Parque Tagua Tagua and M.I for her valuable comments and suggestions.

\section{References}

1. DE LOS RÍOS-ESCALANTE P., Crustacean zooplankton communities in Chilean inland waters. Crustaceana Monographs 12, 1, 2010.

2. BALSEIRO E.G., MODENUTTI B.E., QUELIMAÑOS C.P., REISSIG M. 2007. Daphnia distribution in Andean Patagonian lakes: effect of low food quality and fish predation. Aquatic Ecology, 41, 599, 2007.

3. WOELFL S., GARCÍA P., DUARTE C. Chlorella-bearing ciliates (Stentor, Ophrydium) dominate in an oligotrophic Deep North Patagonian lake (Lake Caburgua, Chile). Limnologica- Ecology and Management of Inland Waters, 40, 134, 2010.

4. SOTO D., CAMPOS H., STEFFEN W., PARRA O., ZUNIGA L. The Torres del Paine lake district (Chilean Patagonia): a case of potentially N-limited lakes and ponds. Arch. Hydrobiol., 99 (1/2), 181, 1994.

5. DE LOS RÍOS-ESCALANTE P., QUINAN E., ACEVEDO P. Crustacean zooplankton communities in lake General Carrera $\left(46^{\circ} \mathrm{S}\right)$ and their possible association with optical properties. Crustaceana, 86, 507, 2013.

6. ARAYA J.M., ZÚÑIGA L. Manual taxonómico del zooplancton lacustre de Chile. Bol. Limnol, Univ. Austral de Chile, 8, 110, 1985.

7. BAYLY I.A.E., Fusion of the genera Boeckella and Pseudoboeckella (Copepoda) and a revision of their species from South America and sub-Antarctic islands. Rev. Chilena Hist. Nat., 65, 17, 1992

8. DE LOS RIOS P., SOTO D., MANSILLA A. Comunidades zooplanctónicas en lagos del parque nacional Torres del Paine: un nuevo enfoque de análisis de factores reguladores de su estructura comunitaria. Anales del Instituto de la Patagonia, 38, 111, 2010.

9. DE LOS RÍOS P., SOTO D., Estudios limnológicos en lagos y lagunas del Parque Nacional Torres del Paine $\left(51^{\circ} \mathrm{S}\right.$, Chile). Anales Instituto Patagonia 37, 63, 2009.

10. PASQUINI A.I., DEPETRIS P.J., Southern Patagonia's Perito Moreno Glacier, Lake Argentino and Santa Cruz river hydrological system: an overview. Journal of Hydrology, 405, 48, 2011.

11. LASPOUMADERES C., MODENUTTI B., SOUZA M., BASTIDAS M., CUASSOLO F., BALSEIRO E., Glacier melting and stoichiometric implications for lake community structure: zooplankton species distributions across a natural light gradient. Global Change Biology, 19, 316, 2013. 
12. HYLANDER S., JEPHSON T., LEBRET K., VON EINEM J., FAGEBERG T., BALSEIRO E., MODENUTTI, B., SOUZA M., LASPOUMADERES C., JÖHNSON, M., LJUNGBERG P., NICOLLE A., NILSSON P.A., RANAKER L., HANSSON L.A. Climate-induced imput of turbid glacial meltwater affects vertical distribution and community com- position of phyto- and zooplankton. Journal of Plankton Research, 33, 1239, 2011.

13. SOMMARUGA R., KANDOLF G. Negative consequences of glacial turbidity for the survival of freshwater planktonic heterotrophic flagellates. Science Reports 4, 4113, 2014. 